\title{
BIODEGRADATION OF OLIVE MILL WASTEWATER BY TRICHOSPORON CUTANEUM AND GEOTRICHUM CANDIDUM
}

\author{
Tibela LANDEKA DRAGIČEVIĆ르, Marijana ZANOŠKI HREN ${ }^{1}$, Margareta GMAJNIĆ', \\ Sanja PELKO ${ }^{1}$, Dzoko KUNGULOVSKI ${ }^{2}$, Ivan KUNGULOVSKI ${ }^{2}$, Domagoj ČVEK ${ }^{1}$, \\ Jadranka FRECE ${ }^{1}$, Ksenija MARKOV ${ }^{1}$, and Frane DELAS̆ ${ }^{1}$
}

Faculty of Food Technology and Biotechnology, University of Zagreb, Zagreb, Croatial , Faculty of Natural Sciences, Gazi Baba bb, Sts. Cyril and Methodius University, Skopje, Macedonia ${ }^{2}$

Received in October 2010

Accepted in November 2010

\begin{abstract}
Olive oil production generates large volumes of wastewater. These wastewaters are characterised by high chemical oxygen demand (COD), high content of microbial growth-inhibiting compounds such as phenolic compounds and tannins, and dark colour. The aim of this study was to investigate biodegradation of olive mill wastewater (OMW) by yeasts Trichosporon cutaneum and Geotrichum candidum. The yeast Trichosporon cutaneum was used because it has a high potential to biodegrade phenolic compounds and a wide range of toxic compounds. The yeast Geotrichum candidum was used to see how successful it is in biodegrading compounds that give the dark colour to the wastewater. Under aerobic conditions, Trichosporon cutaneum removed $88 \%$ of COD and $64 \%$ of phenolic compounds, while the dark colour remained. Geotrichum candidum grown in static conditions reduced COD and colour further by $77 \%$ and $47 \%$, respectively. This investigation has shown that Trichosporon cutaneum under aerobic conditions and Geotrichum candidum under facultative anaerobic conditions could be used successfully in a two-step biodegradation process. Further investigation of OMW treatment by selected yeasts should contribute to better understanding of biodegradation and decolourisation and should include ecotoxicological evaluation of the treated OMW.
\end{abstract}

KEY WORDS: decolourisation, detoxification, phenolic compounds, yeasts

World olive oil production is estimated to around 1.5 to 1.7 million $t$ a year. The EU countries alone produce $75 \%$ of the world production (1). Extraction process yields oil (which accounts for $20 \%$ of the total mass) and two by-products: a solid residue ( $30 \%$ of the total), and a black wastewater $(50 \%$ of the total) called olive mill wastewater (OMW) (2). OMW is composed of the washing and processing water, vegetation water of olives, soft pulp tissue, and oil in the form of a very stable emulsion (3). OMW is an important polluter due to dark colour and high concentration of organic and phenolic compounds, which make OMW toxic and resistant to biological degradation (4). The organic load of OMW, expressed as chemical oxygen demand (COD; range $80 \mathrm{~g} \mathrm{~L}^{-1}$ to $200 \mathrm{~g} \mathrm{~L}^{-1}$ ) and biochemical oxygen demand (BOD; $50 \mathrm{~g} \mathrm{~L}^{-1}$ to $100 \mathrm{~g} \mathrm{~L}^{-1}$ ) is 200 to 400 times higher than in a typical municipal sewage (5). The organic fraction includes sugars, tannins, polyphenols, polyalcohols, pectins, and lipids. The phenolic fraction is recalcitrant to biodegradation and is responsible for several biological affects including phytotoxicity and antibiosis $(4,6,7)$. Literature also reports that OMW toxicity is owed to high organic load, phenolic 
compounds, free fatty acids, low $\mathrm{pH}$, low dissolved oxygen (DO), high total suspended solids, and tannins (7-9). Some claim that OMW toxicity does not depend on extraction procedure (8), while others report that OMW from the continuous process is less toxic that from the traditional (10). The concentration of phenolic compounds in OMW may reach $5 \mathrm{~g} \mathrm{~L}^{-1}$ to $10 \mathrm{~g} \mathrm{~L}^{-1}$ due to higher solubility in the water phase than oil (10-12). The types and concentrations of phenolic compounds in OMW vary tremendously with region, type of used process, conditions of everyday use, and local operational procedure (13). More than 30 different phenolic compounds have been identified in OMW: monocyclic aromatic molecules such as hydroxytyrosol, tyrosol, catechol, methylcatechol, caffeic acid, and compounds with greater molecule mass obtained by their polymerisation $(12,14,15)$.

OMW is an important environmental problem in the Mediterranean countries where it is generated in huge quantities over short periods of time. Discharge of OMW directly into soil may affect its physical and chemical properties such as porosity and $\mathrm{pH}$, but the main problem, due to the direct use of OMW for irrigation, is the presence of phenolic compounds which are phytotoxic and can inhibit seed germination (16).

In the past two decades, many processes have been investigated in order to reduce the toxicity of OMW and to use it as food or raw material in various biotechnological processes $(1,13,17,18)$. Treatment and reuse of OMW presents significant challenges both due to the nature of olive oil production and due to the characteristics of the wastewater (high COD, high phenolic content, and dark colour) (13). A number of different microorganisms and processes have been tested to treat OMW (13). Biological processes investigated for OMW treatment are aerobic and anaerobic (6-11). The major problem with anaerobic processes is the inhibition of anaerobic microorganisms by phenolic compounds and long-chain fatty acids present in OMW and their persistence in effluent (13). A build up of recalcitrant phenolics such as condensed tannins is also reported (19). Aerobic treatment with activated sludge is only efficient for diluted wastewater, because phenolic compounds present in the wastewater inhibit the activity of the activated sludge microorganisms (20).

Literature reports about degradation of phenol (2124 ) and phenolic compounds extracted from OMW (24) by the yeast Trichosporon cutaneum. Other yeasts of the genus Geotrichum (12, 13, 15, 25-27), Candida
$(7,10,28)$ and Yarrowia (28), moulds $(13,25)$ and white-rot fungi $(13,25)$ have also been investigated in studies of OMW biodegradation.

Phenol removal is an important step in OMW biodegradation and environmental protection. The other significant component of environmental pollution is the dark colour that is to be removed during OMW treatment before discharge.

The purpose of this study was to investigate OMW biodegradation by Trichosporon cutaneum and Geotrichum candidum. T. cutaneum was used because of its potential to degrade phenolic compounds in wastewaters of different origin (21). G. candidum was isolated from the investigated OMW and used in decolourisation experiments, because of its known enzymatic potential for OMW decolourisation (27). The main goal was to remove phenol compounds by $T$. cutaneum to reduce the OMW toxicity and the second goal was to remove the dark colour in so treated OMW using G. candidum.

\section{MATERIALS AND METHODS}

\section{Wastewater}

Olive mill wastewater used in this study was obtained from a local olive oil manufacturer (Croatia). OMW was centrifuged at $5000 \mathrm{x}$ g for $10 \min \left(5^{\circ} \mathrm{C}\right)$ (Beckman J-21B, USA) to remove suspended solids, and stored at $-20{ }^{\circ} \mathrm{C}$. The main chemical and physical characteristics of raw OMW, expressed as mean values \pm standard deviation ( $\mathrm{n}=3$ ), were: $\mathrm{pH}(5.5 \pm 0.1), \mathrm{COD}$ (54 \pm 0.6$) \mathrm{g} \mathrm{L}^{-1}$, total suspended solids $(42 \pm 1) \mathrm{g} \mathrm{L}^{-1}$, total phenols $(9.2 \pm 0.2) \mathrm{g} \mathrm{L}^{-1}$, and total nitrogen $(0.9 \pm 0.1) \mathrm{g} \mathrm{L}^{-1}$. $\mathrm{pH}$ was measured using a $\mathrm{pH}$ meter (WTW 320, Germany). COD is used as a measure of the oxygen equivalent of the organic matter content of a sample that is susceptible to oxidation by a strong chemical oxidant. It was determined using the APHA standard closed reflux method (5520 C) (29). Total suspended solids (TSS) were determined by filtering known volume of sample through a previously weighed and dried filter paper (at $103{ }^{\circ} \mathrm{C}$ to $105^{\circ} \mathrm{C}$, overnight), then dried overnight to the constant weight (at $103{ }^{\circ} \mathrm{C}$ to $105^{\circ} \mathrm{C}$ ) according to the APHA standard method $2540 \mathrm{D}$ (29), and expressed in $\mathrm{g} \mathrm{L}^{-1}$. Total phenols were determined using the Folin-Ciocalteu's phenol reagent (Fluka, Switzerland) (30) and total nitrogen (N-tot) was analysed photometrically (Merck 
Spectroquant ${ }^{\circledR}$ Vega 400) with standard kits (MerckSpectroquant, Germany). Prior to biological treatment, $\mathrm{pH}$ was adjusted to 6 with $2 \mathrm{~mol} \mathrm{~L}^{-1} \mathrm{NaOH}$ (Grammol, Croatia). For aerobic experiments, OMW was diluted with tap water to the initial value of the COD and phenols of (11.8 \pm 0.3$) \mathrm{g} \mathrm{L}^{-1}$ and $(2 \pm 0.13) \mathrm{g} \mathrm{L}^{-1}$, respectively. Aerobically treated OMW, with addition of glucose (Gram-mol, Croatia) as carbon source $\left(1 \mathrm{~g} \mathrm{~L}^{-1}\right)$ was used for further decolourisation with G. candidum. UV-spectrophotometric measurements of colour intensity were performed with a UV-VIS spectrophotometer (Pye Unicam, Helios beta, UK) at $390 \mathrm{~nm}$.

Yeasts

Yeasts T. cutaneum and G. candidum used in this research belong to the collection of microorganisms of the Laboratory for Biological Wastewater Treatment, Faculty of Food Technology and Biotechnology, University of Zagreb. T. cutaneum was isolated from activated sludge used to treat oil refinery wastewater (21) while G. candidum was isolated from the investigated OMW.

The strains were identified using the API Candida System (bioMérieux, France), maintained on a yeast growth medium (YGM) solidified with agar (14 $\mathrm{g} \mathrm{L}^{-}$ ${ }^{1}$, Biolife, Italy) and on diluted OMW (40\%, v/v) solidified with agar $\left(14 \mathrm{~g} \mathrm{~L}^{-1}\right.$, Biolife, Italy). They were replicated every month. The composition of YGM was: glucose $\left(20 \mathrm{~g} \mathrm{~L}^{-1}\right.$, Gram-mol, Croatia), bacto peptone (10 $\mathrm{g} \mathrm{L}^{-1}$, Difco, USA), and yeast extract (5 $\mathrm{g} \mathrm{L}^{-1}$, Biolife, Italy).

For experiments with phenol removal, the biomass of $T$. cutaneum grown on YGM agar plates (at $28^{\circ} \mathrm{C}$ for three days) was transferred in $500 \mathrm{~mL}$ Erlenmeyer flasks with $100 \mathrm{~mL}$ of YGM and with diluted and sterilised (at $121{ }^{\circ} \mathrm{C}$ for $30 \mathrm{~min}$ ) OMW in a volume portion of $30 \%$ to $50 \%$, and incubated on a rotary shaker (Certomat IS, Sartorius, Germany) at $150 \mathrm{rpm}$ and $28^{\circ} \mathrm{C}$. After three days of cultivation, the biomass was centrifuged at $5000 \mathrm{x} \mathrm{g}$ and $5{ }^{\circ} \mathrm{C}$ for $10 \mathrm{~min}$, washed with sterile saline solution, and the suspension of so prepared biomass used as inoculum in the OMW biodegradation experiment.

For the OMW decolourisation experiment, $G$. candidum grown on YGM agar plates (at $30{ }^{\circ} \mathrm{C}$ for three days) was transferred in $500 \mathrm{~mL}$ Erlenmeyer flasks containing $100 \mathrm{~mL}$ YGM with aerobically treated OMW (in volume portion of $50 \%$ to $60 \%$ ) and incubated at $30^{\circ} \mathrm{C}$. After three days of cultivation, the biomass was centrifuged at $5000 \mathrm{x}$ g and at $5{ }^{\circ} \mathrm{C}$ for $10 \mathrm{~min}$, washed with sterile saline solution and used as inoculum.

All cultures were grown in triplicates.

\section{Experimental methods}

The experiments were carried out in $2 \mathrm{~L}$ glass serum bottles with working volume of $1.5 \mathrm{~L}$ and at ambient temperature. Serum bottles were equipped with an aeration system that included an air pump (SPP-40GJ-L, Techno Takatsuki Co., LTD, Japan), a silicone tube (Tecno Plast, Germany), a sterile filter unit (pore size 0,45 $\mu \mathrm{m}$, Wathman, Germany), and a sterile serological pipette (10 mL, TPP, EU). Constant air flow ensured sufficient oxygenation of the mixture by bubbling.

OMW was biodegraded by $T$. cutaneum under aerobic conditions (dissolved oxygen $2.5 \mathrm{mg} \mathrm{L}^{-1}$ to $3.5 \mathrm{mg} \mathrm{L}^{-1}$ ) and at $\mathrm{pH} 6.0$ to 6.5. The dark colour of so treated OMW persisted. At the end of the experiment with $T$. cutaneum aeration was stopped, the biomass separated by centrifugation at $5000 \mathrm{x}$ g and $5{ }^{\circ} \mathrm{C}$ for $10 \mathrm{~min}$, and the supernatant was then treated with $G$. candidum.

Decolourisation experiment with G. candidum was performed under static conditions (dissolved oxygen $0.5 \mathrm{mg} \mathrm{L}^{-1}$ to $0.8 \mathrm{mg} \mathrm{L}^{-1}$ ) because static conditions improve decolourisation (15).

All experiments were performed in triplicate. Control experiments were done without inoculation with biomass.

\section{Statistical analysis}

Results presented are mean values \pm standard deviation. Statistical analysis was performed using Student's $t$-test and Pearson's correlation coefficient to test the differences between variables. Statistical significance was set at $\mathrm{P}<0.05$.

\section{RESULTS AND DISCUSSION}

Efficient treatment of olive oil industry wastewaters is a difficult task, as they contain many phenolic compounds and other toxic and biomass growth inhibiting compounds (11).

OMW is recalcitrant to conventional wastewater treatment, and its management and disposal present a serious environmental problem (8). The removal of phenolic compounds is therefore the first step in OMW biodegradation and detoxification (24). For 
that purpose, many types of yeast were successfully used $(7,10,13,28)$. In this study we used $T$. cutaneum because it has the greatest phenolic biodegradation potential for wastewaters of different origin among the yeasts of the Trichosporon genus (21-24).

T. cutaneum used in this study was isolated from activated sludge originating from a system for biological treatment of oil refinery wastewater (21). It has been reported for degradation of phenol and other toxic compounds simultaneously as model compounds or present in wastewater (21-23) and phenolic fraction from OMW (24).

In our research the ability of $T$. cutaneum for phenolic compounds removal, and the effect of OMW composition on their growth and activity for OMW degradation was investigated in real OMW. Because of inhibitory effects of phenolic compounds on microorganisms in this research was used OMW diluted with tap water $(11,15,26,27)$.

Figure 1 shows removal of total phenols from OMW with T. cutaneum. Degradation of phenolic components was accompanied by biomass growth, $\mathrm{COD}$ reduction and $\mathrm{pH}$ decrease. In the first $18 \mathrm{~h}, \mathrm{pH}$ decreased to 5.85 and then increased to 6.16 by the end of the experiment. There was no colour reduction. Under aerobic conditions, the reduction of COD and phenols over $54 \mathrm{~h}$ was $88 \%$ and $64 \%$, respectively. Also, the increase in biomass concentration (Figure 1) confirmed that $T$. cutaneum utilised OMW compounds for its growth. In control experiments, there were no significant changes in COD (Figure 1).
A previous study (21) reported that $T$. cutaneum decomposed $1.5 \mathrm{~g} \mathrm{~L}^{-1}$ of phenol, as a sole source of carbon and energy over $50 \mathrm{~h}$. Similarly, $2 \mathrm{~g} \mathrm{~L}^{-1}$ of phenol was degraded after $48 \mathrm{~h}$ (24) and with lag phase (18 h). However, Chtourou et al. (24) observed that phenol concentrations above $2.5 \mathrm{~g} \mathrm{~L}^{-1}$ were inhibitory. In our investigation biodegradation of $(1.96 \pm 0.03) \mathrm{g} \mathrm{L}^{-1}$ total phenols in OMW was achieved in $54 \mathrm{~h}$ without the lag phase (Figure 1). This result confirms high enzymatic activity of $T$. cutaneum for phenol reduction.

The literature data (24) reported that $T$. cutaneum was able to grow on phenolic compounds extracted in ethyl acetate from OMW. The removal of phenols was $90.6 \%$ (from initial $2 \mathrm{~g} \mathrm{~L}^{-1}$ ) as well as COD removal (from initial $19 \mathrm{~g} \mathrm{~L}^{-1}$ ) during 8 days. By HPLC analysis it was confirmed the degradation and transformation of phenolic compounds and formation of new compounds that persisted degradation.

However, this first-pass removal of phenolic compounds and COD reduction under aerobic conditions did not remove the OMW's dark colour. This colour is owed to polyphenols, phenolic compounds with high molecular weights that are not easily biodegraded $(1,26,27)$. This is why we used G. candidum in the second pass, as it is known to depolymerise polyphenols and produce enzymes that decolour OMW (11-13, 25-27). The results of decolourisation of aerobically treated OMW with $G$. candidum are shown in Figure 2. Over the six days of the experiment, the treatment with $G$. candidum

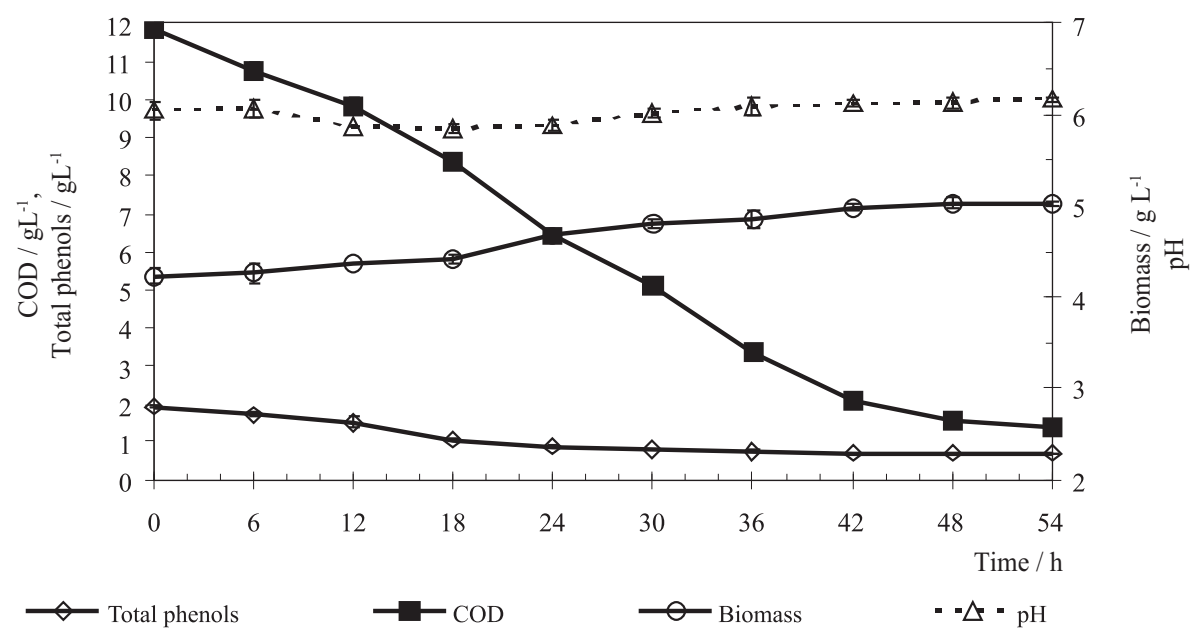

Figure 1 Variations in COD, total phenols, biomass, and $\mathrm{pH}$ during aerobic degradation of OMW using T. cutaneum (average $\pm S D ; n=3)$. When the error bar is not visible it is within the data point. 


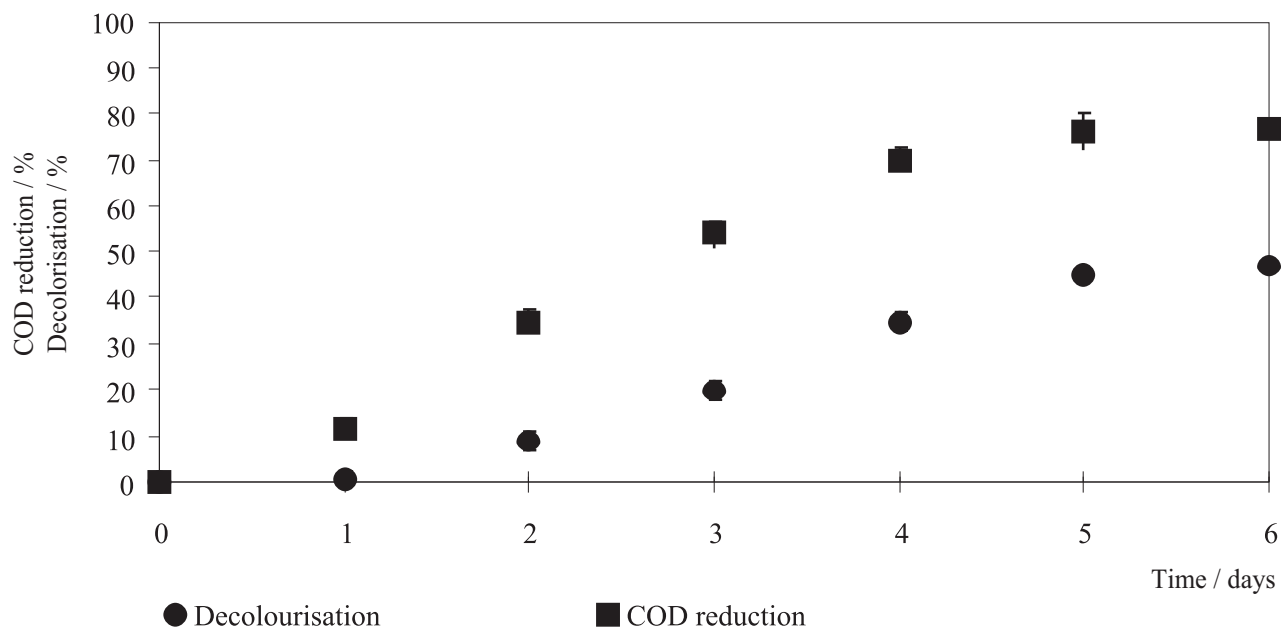

Figure 2 COD reduction and decolourisation during facultative anaerobic degradation of aerobically treated OMW using $G$. candidum (average $\pm S D ; n=3$ ). When the error bar is not visible it is within the data point.

removed $77 \%$ of COD and reduced colour by $47 \%$. The biomass concentration increased insignificantly. A decrease in $\mathrm{pH}$ (data not presented) suggests that the remaining phenolic compounds were biodegraded to products which lower $\mathrm{pH}$. Similar was reported elsewhere for G. candidum $(11,26,27)$. All changes observed during aerobic treatment of OMW under facultative anaerobic conditions indicate high enzymatic activity of $G$. candidum in biodegradation of less readily biodegradable compounds, especially those that give colour. A number of studies investigated different conditions of G. candidum growth and OMW decolourisation $(11,15)$. Some have pointed out the importance of the addition of an easily biodegradable carbon source for lignin peroxidase production and the biomass growth $(11,12,27)$. In our decolourisation experiments with G. candidum glucose was used as carbon source. It was also noted that $G$. candidum possessed the ability to decolourise fresh OMW, but when it was incubated with stored black OMW as the sole carbon source, there was no decolourisation. Therefore, glucose seems to play an important role in the Geotrichum decolourisation process (26).

\section{CONCLUSIONS}

Because of OMW's composition and environmental issues involved, it is necessary to control its disposal and develop new technologies to reduce pollution. However, this may present a considerable technical and economic challenge, not only because of the complex composition of OMW, but also because of the seasonal nature of olive oil production and wide geographical dispersion of mills. Effective biotreatment of OMW that significantly reduces COD, phenolic compounds, and colour allows for safe and economical disposal of OMW into soil or into surface waters. Further investigation of OMW treatment by selected yeasts should contribute to a better understanding of the processes of biodegradation and decolourisation (production of enzymes, definition of process factors) and should include ecotoxicological evaluation of the treated OMW.

\section{Acknowledgement}

This study has been supported by the Croatian Ministry of Science, Education and Sports (grant no. 058-0583444-3494).

\section{REFERENCES}

1. Hamdi M. Future prospects and constraints of olive mill wastewaters use and treatments: a review. Bioprocess Eng 1993;8:209-14.

2. Martin A, Borja R, Garcia I, Fiestas JA. Kinetics of methane production from olive mill wastewater. Process Biochem 1991;26:101-7.

3. Ayed L, Hamdi M. Fermentative decolorization of olive mill wastewater by Lactobacillus plantarum. Process Biochem 2003;39:59-5

4. Mekki A, Dhouib A, Sayadi S. Polyphenols dynamics and phytotoxicity in a soil amended by olive mill wastewaters. J Environ Manage 2007;84:134-40. 
5. Cossou R, Blakey N, Cannas P. Influence of co-disposal of municipal solid waste and olive vegetation water on the anaerobic digestion of a sanitary landfill. Water Sci Technol 1993;27:261-71.

6. Aggelis G, Inconomou D, Christou M, Bokas D, Kotzailias S, Christou G, Tsgou V, Papanikolaou S. Phenolic removal in a model olive oil mill wastewater using Pleurotus ostreatus in bioreactor cultures and biological evaluation of the process Water Res 2003;37:3897-904.

7. Peixoto F, Martins F, Amaral C, Gomez-Laranjo J, Almeida J, Palmeira CM. Evaluation of olive oil mill wastewater toxicity on the mitochondrial bioenergetics after treatment with Candida oleophila. Ecotoxicol Environ Safety 2008;70:26675.

8. Paixão SM, Mendonça E, Picado A, Anselmo AM Acute toxicity evaluation of olive mill wastewaters: a comparative study of tree aquatic organisms. Environ Toxicol 1999; $14: 263-9$

9. Amaral C, Lucas MS, Coutinho J, Crespí AL, do Rosário Anjos M, Pais C. Microbiological and physicochemical characterization of olive mill wastewaters from a continuous olive mill in Northeastern Portugal. Bioresour Technol 2008;99:7215-23.

10. Ben Sassi A, Ouazzani N, Walker GM, Ibnosouda S, El Mzibri M. Detoxification of olive mill wastewaters by Moroccan yeast isolates. Biodegradation 2008;19:337-46.

11. Fadil K, Chahlaoui A, Ouahbi A, Zaid A, Borja R. Aerobic biodegradation and detoxification of wastewaters from the olive oil industry. Int Biodet Biodeg 2003;51:37-41.

12. Asses N, Ayed L, Bouallagui H, Sayadi S, Hamdi M. Biodegradation of different molecular-mass polyphenols derived from olive mill wastewater by Geotrichum candidum. Int Biodet Biodeg 2009;63:407-13.

13. McNamara CJ, Anastasiou CC, O'Flaherty V, Mitchell R. Bioremediation of olive mill wastewater. Int Biodet Biodeg 2008;61:127-34.

14. Tziotzios G, Michailakis S, Vayenas DV. Aerobic biological treatment of olive mill wastewater by olive pulp bacteria. Int Biodet Biodeg 2007;60:209-14.

15. Asses N, Ayed L, Bouallagui H, Ben Rejeb I, Gargouri M, Hamdi M. Use of Geotrichum candidum for olive mill wastewater treatment in submerged and static culture. Bioresour Technol 2009;100:2182-8.

16. Saadi I, Laor Y, Raviv M, Medina S. Land spreading of olive mill wastewater: effects on soil microbial activity and potential phytotoxicity. Chemosphere 2007;66:75-83.

17. Roig A, Cayuela mL, Sánchez-Monedero MA. An overview on olive mill wastes and their valorisation methods. Waste Manage 2006;26:960-9.

18. El Hajjouji H, Ait Baddi G, Yaacoubi A, Hamdi H, Winterton P, Revel JC, Hafidi M. Optimisation of biodegradation conditions for the treatment of olive mill wastewater. Bioresour Technol 2008;99:5505-10.

19. Hamdi M. Toxicity and biodegradability of olive mill wastewaters batch anaerobic digestion. Appl Biochem Biotechnol 1992;37:155-62.

20. Borja R, Martin A, Maestro R, Alba J, Fiestas JA. Enhancement of the anaerobic digestion of olive mill wastewater by the removal of phenolic inhibitors. Process Biochem 1992;27:231-7.

21. Dvoraček L, Glancer M, Ban S. Degradation of phenol in industrial waste waters. Part I: Selection of microorganisms. Prehrambeno-Tehnol Biotehnol Rev 1989;27:147-54.

22. Aleksieva Z, Ivanova D, Godjevargova T, Atanasov B. Degradation of some phenol derivatives by Trichosporon cutaneum R57. Process Biochem 2002;37:1215-9.

23. Godjevargova T, Ivanova D, Alexieva A, Dimova N. Biodegradation of toxic organic components from industrial phenol production waste waters by free and immobilized Trichosporon cutaneum R57. Process Biochem 2003;38:91520.

24. Chtourou M, Ammar E, Nasri M, Medhioub K. Isolation of a yeast, Trichosporon cutaneum, able to use low molecular weight phenolic compounds: application to olive mill waste water treatment. J Chem Technol Biotechnol 2004;79:86978.

25. García García I, Jiménez Peña PR, Bonilla Venceslada JL, Martín Martín A, Martín Santos MA, Ramos Gómez E. Removal of phenol compounds from olive mill wastewater using Phanerochaete chrysosporium, Aspergillus niger, Aspergillus terreus and Geotrichum candidum. Process Biochem 2000;35:751-8.

26. Assas N, Ayed L, Marouani L, Hamdi M. Decolorization of fresh and stored-black olive mill wastewaters by Geotrichum candidum. Process Biochem 2002;38:361-5.

27. Ayed L, Assas N, Sayadi S, Hamdi M. Involvement of lignin peroxidase in the decolourization of black olive mill wastewaters by Geotrichum candidum. Lett Appl Microbiol 2005;40:7-11.

28. Gonçalves C, Lopes M, Ferreira JP, Belo I. Biological treatment of olive mill wastewater by non-conventional yeasts. Bioresour Technol 2009;100:3759-63.

29. Clesceri LS, Greenberg AE, Rhodes Trussell R, editors. Standard Methods for the Examination of Water and Wastewater. 20 ${ }^{\text {th }}$ edition. Washington (DC): American Public Health Association, American Water Works Association and Water Pollution Control Federation; 1998.

30. Waterman PG, Mole S. Analysis of phenolic plant metabolites. In: Lawton JH, Likens GE, editors. Methods in ecology. Oxford: Blackwell Scientific; 1994. p. 83-5. 


\section{Sažetak}

\section{BIORAZGRADNJA OTPADNE VODE IZ PROCESA PROIZVODNJE MASLINOVA ULJA S POMOĆU TRICHOSPORON CUTANEUM I GEOTRICHUM CANDIDUM}

Tijekom proizvodnje maslinova ulja nastaju velike količine otpadne vode. Karakterizira je visoka kemijska potrošnja kisika (KPK), visoka koncentracija sastojaka koji inhibiraju rast mikroorganizama, poput fenolnih spojeva i tanina i tamna boja. Cilj ovog rada je bio istražiti biorazgradnju otpadne vode iz procesa proizvodnje maslinova ulja s pomoću kvasaca Trichosporon cutaneum i Geotrichum candidum. Kvasac Trichosporon cutaneum u ovom je istraživanju uporabljen zbog svog visokog potencijala za biorazgradnju fenolnih i drugih toksičnih spojeva. Kvasac Geotrichum candidum uporabljen je kako bi se istražilo koliko je uspješan u biorazgradnji spojeva koji otpadnoj vodi daju tamnu boju. Pri aerobnim uvjetima Trichosporon cutaneum uklonio je 88 \% KPK i 64 \% fenolnih spojeva, dok tamna boja otpadne vode preostaje. Geotrichum candidum u statičkim je uvjetima smanjio KPK i boju za 77 \%, odnosno $47 \%$. Ovo je istraživanje pokazalo da Trichosporon cutaneum pri aerobnim uvjetima i Geotrichum candidum pri fakultativno anaerobnim uvjetima mogu biti uspješno uporabljeni u dvostupanjskom procesu biorazgradnje. Daljnje istraživanje obrade otpadne vode iz procesa proizvodnje maslinova ulja s pomoću odabranih kvasaca trebalo bi pridonijeti boljem razumijevanju biorazgradnje i uklanjanju boje i trebalo bi biti provedeno zajedno sa ekotoksikološkim vrednovanjem obrađene otpadne vode.

KLJUČNE RIJEČI: detoksifikacija, fenolni spojevi, kvasci, obezbojenje

\section{CORRESPONDING AUTHOR:}

Tibela Landeka Dragičević

Faculty of Food Technology and Biotechnology,

University of Zagreb

Pierotti Str. 6, 10000 Zagreb, Croatia

E-mail: tdragic@pf.hr 